DOI: $10.1515 / \mathrm{rpp}-2015-0059$

Doctor of Pedagogical Sciences, Associate Professor, VASYL KOVALCHUK National University of Life and Environmental Sciences of Ukraine Address: 16 Heroiv Oborony St., Kyiv, 03041, Ukraine E-mail: shuparka@ list.ru

\title{
TEACHING STAFF ADVANCED TRAINING IN RUSSIA, THE REPUBLIC OF KAZAKHSTAN, THE USA AND CANADA
}

\begin{abstract}
In the article the peculiarities in organization of postgraduate teacher training in foreign countries have been highlighted; the basic problems and prospects for advanced training which stipulate for reforming the relevant national systems have been revealed; common and distinctive trends in their development have been justified. In Russia there is a cascade (cyclic) system of teaching staff advanced training, based on the principles of andragogy, namely, continuity, self-control and self-analysis of professional activities by teachers and the use of their own experience during the advanced training. The abovementioned system consists of three phases such as pre-course, course and implementing. Each element of this model is a constituent part of the other, providing cycling and growth. Tasks for teachers are grounded on all the phases of the described system and influence their professional development. In the Republic of Kazakhstan there are three basic systems for teaching staff advanced training, namely, centers of educational excellence at the "Nazarbayev Intellectual Schools", JSC "National Centre of Teaching Staff Advanced Training" (based on RIPKSO and 16 regional teaching staff advanced training institutes), teaching staff advanced training centres at universities and experimental sections. According to the defined module in the terms of the complex 3-month courses combining face-to-face and online training are provided. In the USA advanced training is provided by multilevel higher educational institutions which offer a wide range of different full-time and distance training programs and some programs are taught directly in educational establishments. The content of advanced training is determined by standards of professional pedagogical education according to the educational program and provides for fundamental, psychological, pedagogical, methodical, IT, practical, social and humanitarian training. Teaching staff advanced training in Canada is provided by various educational establishments, departments of education, school boards, regional centers of education, teachers unions and private providers of professional development services.

Key words: advanced training, postgraduate education, teaching staff, teachers' professional development, continuing education, Russia, Kazakhstan, the USA, Canada.

\section{INTRODUCTION}

Over the last decades teacher's profession in Ukraine has become non-prestigious, and teachers are losing their qualifications due to lack of effective motivation and striving for self-development. Traditional advanced training does not satisfy their real needs for development and prove to be ineffective. So, one of the important problems of education reforming are substantial changes in the system of postgraduate education, including the search for new models of its organization.
\end{abstract}


THE AIM OF THE STUDY

The aim of the study is to analyze the experience of teaching staff advanced training in near and far abroad countries.

\section{THEORETICAL FRAMEWORK AND RESEARCH METHODS}

Advanced training is carried out according to the Laws of Ukraine "On Education", "On Higher Education", "On Scientific and Technical Activity", "Regulations on Teaching Staff Advanced Training and Internship" and other legal documents.

The problem of improving postgraduate pedagogical education system that contributes to the development of teaching staff professional competency has been studied in the works by T. Ageykina-Starchenko, A. Bodnarchuk, M. Byrka, L. Danylenko, L. Karamushka N. Klokar, V. Kovalchuk, V. Maslov, V. Oliynyk, V. Palamarchuk, V. Putsov, V. Semychenko, L. Sigayev, T. Sorochan, T. Sushchenko, L. Vashchenko, N. Vasylenko and others. Foreign experience of postgraduate education has been studied by N. Abashkina, V. Gamanyuk, N. Kozak, A. Leontyev, N. Postrygach, O. Protsenko, L. Puhovska, S. Synenko, S. Sysoyeva, T. Vakulenko and others.

The main methods used to achieve the aim of the study are theoretical analysis and synthesis of philosophical, pedagogical and psychological literature on teaching staff advanced training, that enabled the justification of the process' identity in near and far abroad countries and the main approaches to its organization in education.

\section{RESULTS}

Most post-Soviet countries, including Ukraine, inherited the Soviet system of teaching staff advanced training. However, for 24 years globalization and internationalization processes have contributed to the arising of certain features for its development.

System of teaching staff training and retraining in Russia includes 94 educational establishments located in all regions and is chaired by the Academy of Teaching Staff Training and Retraining (Moscow) (Академия повышения квалификации и профессиональной переподготовки работников образования, 2015). More than 2500 municipal methodical establishments coordinated by the Academy take part in continuing professional development of teaching staff (Синенко, 2010).

Current trends are putting forward new requirements to teacher's training, resulted in radical reforming of postgraduate pedagogical education. A range of teacher trainers' responsibilities has been increased, namely, organization of innovation and research activities; marketing and sociological researches; paid services organization; information support for schools; information processing, etc. Otherwise methodical services provided by institutes of postgraduate pedagogical education are inefficient (Гагарина, 2005).

We should take into account the experience of the Novosibirsk Teachers' Professional Retraining Institute where a cascade (cyclic) system of teaching staff advanced training based on the principles of andragogy, namely, continuity, self-control and selfanalysis of professional activities by teachers and the use of their own experience during the advanced training is being implemented (Синенко, 2012). The abovementioned system consists of three phases such as pre-course, course and implementing.

Pre-course phase includes: 1) study of the national qualifications framework; 2) evaluation of teacher's professional development level, namely self- and external evaluation; 3) professional development project (the problem studied by the teacher; tasks to do; learning outcomes, etc.). Course phase combines: 1) discussing and adjusting of the professional development project with the help of heads of the courses; 2) making a program for the project implementing and its actual implementation, i.e. the courses themselves; 3) defending of the development project. 
Implementing phase includes: 1) acquainting of methodological units and educational establishments' staff with the process of advanced training - teachers report to the leadership of their educational institutions and colleagues in a convenient form (seminar etc.) on the work they were engaged in, introduce their projects, its structures and set objectives;2) implementing of advanced training results - teachers demonstrate knowledge they obtained during master classes, open lessons and seminars in the context of their projects on professional development; participation in conferences and seminars; 4) identifying of problem areas in the professional development of teachers as a result of practice through self-evaluation and external evaluation (Синенко, 2012). Each element of this model is a constituent part of the other, providing cycling and growth.

The system of management and teaching staff advanced training in Kazakhstan is represented by 14 regional, 2 municipal (Astana, Almaty) institutes of teaching staff advanced training and 7 centers of teacher staff advanced training at pedagogical institutes (Ахметова, 2011).

Regional and municipal institutes of staff training in Astana and Almaty organize advanced training courses according to applications of educational establishments based on the specific needs of listeners. Curricula are based on the module technology. The elements of credit system are being implemented into the content of courses. The programs are based on the modular technology including classes (about 60 percent of time) and extracurricular activities. Course programs include consultations and self-study. At the regional level institutes of staff training provide courses various in duration and forms. Most common are 72-hour and 36-hour full-time courses. Also, institutes of staff training provide correspondence training courses, two-sessional courses, three-sessional courses, self-supporting 3-day courses (Анализ планов повышения квалификации педагогических работников, учебных программ областных институтов повышения квалификации педагогических кадров РК на 2011 год, 2011).

According to "State Program of Education Development in the Republic of Kazakhstan for 2011-2020" the conceptual and structural approaches to reforming the system of advanced training have been defined and three basic complexes of teaching staff advanced training have been established, such as:

1) Centers of Excellence at "Nazarbayev Intellectual Schools" with coverage of 21950 teachers of higher and first category in 2012-2016 - level 1;

2) JSC "National Centre of Teaching Staff Advanced training" (based on Republican Institute for Development of Leading and Research-Pedagogical Staff of Education System of The Republic of Kazakhstan and 16 regional institutions of advanced training) covering 78240 teachers of the first and the second categories - levels 2 and 3;

3) Centers of Teaching Staff Advanced Training at pedagogical institutes and experimental schools attached to these pedagogical institutes with basic coverage of 20,000 teachers of the first and second categories - 2 and 3 level (Анализ планов повышения квалификации педагогических работников, учебных программ областных институтов повышения квалификации педагогических кадров РК на 2011 год, 2011).

The main result of such complexes' activities is to provide a common conceptual approach to teaching staff advanced training. For this matter taking into account foreign experience and the needs of modern schools, "Nazarbayev Intellectual School" in cooperation with the University of Cambridge has designed the content and methodology of multi-level courses including 7 modules, such as new teaching technologies in education; critical thinking; criterion assessment of students' achievements; management in secondary education and training based on competences during the transition to 12-year education; use 
of ICT, e-learning in teaching; modern technologies of working with gifted children; psychological and pedagogical features of teaching in specific age groups of pupils.

The complexes include 3-month courses providing definite modules which combine face-to-face and online training. $60 \%$ of teachers at courses are foreigners, $40 \%$ - domestic. After the courses have been completed teachers pass a qualification exam and receive certificates with a new qualification level $-1,2$ or 3 , which give the right to receive increased salaries (from 30 to $100 \%$ ). At the same time "Nazarbayev Intellectual Schools" are going to develop the system of online interactive seminars for secondary school teachers.

As a result educational sector receives the system of advanced training consistent with international practice in its organizational structure, content and methodology (Исимбаев, 2012).

In the USA advanced training is provided by multilevel higher educational establishments which offer a wide range of advanced training programs of different duration, namely, full-time and distance. Some programs are taught directly at schools. The content of advanced training is determined by standards of professional teacher education according to their specialty and provides for fundamental, psychological, pedagogical, methodical, ICT, practical, social and humanitarian training (Hayes, 1995). An important part of teachers' professional development is played by collegial forms of work, including associations of teachers, the main purpose of which is to improve the quality of education or its certain branches, enhancing students' academic achievements and professional development of teachers (Edge, 1991).

Participation in associations enables a teacher to have free (or discounted) publications in associations' journals, subscribe to professional journals and newsletters, have access to valuable professional publications. It helps teachers to promote themselves and their work in scientific educational circles, be aware of recent developments in the field, read the works of the best professionals. Also, many grant programs are implemented by the government in the system of advanced training.

One of such organizations is "New Leaders for New Schools", a national nonprofit organization that develops brand new school leaders and develops policy and practice for effective leadership in school systems throughout the country. Their theory consists in that strong school leaders give a powerful multiplier effect, greatly improving the quality of teaching and enhance students' achievements at school. Their mission is to provide high achievements for all students, especially those living in poverty and bright students by developing brand new school leaders and promoting such policies and practices that enable strong leaders to succeed.

School system is focused on key activities in leading environment. Teachers who are trained under this program, train teachers in their schools and have the opportunity to receive rewards for their activity. Moreover, $90 \%$ of teachers who completed such courses become principals.

So, the system of advanced training is very widespread in the USA because it has a material basis. It means that the teacher who was trained by any form is able to get a pay raise. Every five years teachers undergo compulsory certification to prove their teachers' licenses, which requires continuous professional development.

Teaching staff advanced training in Canada is provided by various educational establishments, namely universities that offer Bachelor, Master, Doctor degree programs, teacher certification programs; departments of Education that manage the development of national education policy; school boards that implement the programs for days of obligatory and voluntary professional development; regional centers of education that 
analyze the present state of the teaching profession, define its advantages and disadvantages; voluntary associations of subject teachers; teachers unions and private providers of professional development services aimed at organizing professional development training at schools (Мукан, 2007). Funding of teachers' professional development is provided by departments / ministries of education of Canadian provinces. School boards are responsible for adequate funding of teachers' professional development at the individual, school and system levels (Adult Learning and Education, 2012). Association of teachers ensure the availability of professional development opportunities, develop and promote programs of teaching staff advanced training, support the creation of professional development programs, establish committees for pedagogues' professional development. Every teacher association has the division of professional development aimed at studying the problems of teachers in advanced training, development and promotion of practical programs for the association members (The Development of Education in Canada. Report of Canada, 2001). According to the laws of Canada every school develops an annual plan for teachers' professional development, which includes defining the goals of the educational establishment in accordance with national and provincial policies of education development, methods and mechanisms for monitoring their achievements. Every teacher develops an individual plan of professional development according to the defined plan and Teaching Quality Standard of Canada.

\section{CONCLUSIONS}

The performed theoretical analysis of teaching staff advanced training systems has made it possible to define priority trends for the use of foreign experience, which, in our opinion, may be useful in the development of teaching staff advanced training in Ukraine as nowadays there is a need for establishing an effective system of advanced training, which would unite various public and private institutions.

The results of the study on the teaching staff advanced training in near and far abroad countries present an opportunity to apply the best practices to the national system of postgraduate education, taking into account the best results of leading countries, namely, the decentralization of postgraduate pedagogical education; in-service teacher training according to teachers' interests and strategies of developments defined by the educational institution; active cooperation of schools with universities and other advanced training institutions; support from academic staff, authorities, community members; diversity of advanced training forms; organizational support for teachers in advanced training; development of reward systems for teaching staff according to the results of advanced training; the use of distance learning as an alternative form of training and retraining of pedagogues; participation of non-governmental organizations (NGOs) in teaching staff advanced training.

The study does not exhaust the defined problem. Particularly promising could be further research on the establishing of an effective model of teaching staff advanced training in Ukraine according to personal professional development needs.

\section{REFERENCES}

1. Edge, J. (1991). Cooperative Development: Professional development through Cooperation with Colleagues. Harlow : Longman, 110 p.

2. Hayes, D. (1995). In-service Teacher Development: Some Basic Principles. English Language Teaching Journal, Volume 49, No 3, pp. 3-4.

3. The Council of Ministers of Education Canada. (2012). Adult Learning and Education. Canada Progress Report for the UNESCO Global Report on Adult Learning 
and Education (GRALE) and the End of the United Nations Literacy Decade. Retrieved 20.10.2015 from : http://www.cmec.ca/publications/lists/publications/attachments/283/grale en.pdf.

4. The Council of Ministers of Education: Geneva. (2001). The Development of Education in Canada. Report of Canada. Retrieved 16.10.2015 from: http://www.cmec.ca/Publications/Lists/Publications/Attachments/34/ice46devca.en.pdf.

5. Академия повышения квалификаиии и профессиональной переподготовки работников образования [The Academy of Teaching Staff Training and Retraining]. (2015). Retrieved 12.10.2015 from : http://www.apkpro.ru/.

6. Анализ планов повышения квалификачии педагогических работников, учебных программ областных институтов повымения квалификаиии педагогических кадров РК на 2011 год [Analysis of Plans on Teaching Staff Advanced Training, Study Programs of Regional Institutes of Teaching Staff Advanced Training in the Republic of Kazakhstan in 2011]. (2013). Retrieved 3.10.2015 from : http://kk.convdocs.org/download/ docs 97242/97242.doc.

7. Ахметова, Г. (2011). Стратегические ориентиры модернизации системы повышения квалификации в республике Казахстан [Strategic Guidelines for Modernization of Advanced Training System in the Republic of Kazakhstan]. Менеджмент 8 образовании [Management in Education], No 4 (63), pp. 6-12 (in Russian).

8. Гагарина, О. (2005). Условия повышения эффективности функционирования методической службы в системе повышения квалификаиии работников образования [Terms for Enhancing the Effectiveness of Methodical Service Functioning in the System of Postgraduate Pedagogical Education]. Thesis for PhD. Ставрополь : СКИПКРО, 23 p. (in Russian).

9. Исимбаев, Е. (2012). Новые подходы к совершенствованию профессионального мастерства педагогов [New Approaches to Advancing Professional Skills of Pedagogues]. Инфомаиионно-методический журнал «Открытая школа» [Information and Methodical Journal "Otkrytaya Shkola"], No 9 (120). Retrieved 17.10.2015 from : http://w ww.open school.kz/glavstr/tema_nomera/tema_nomera_120_2.htm.

10. Мукан, Н. (2007). Система неперервної професійної освіти педагогів Канади: інституції та їхня діяльність [System of Continuing Pedagogical Education in Canada: Institutions and Their Activities]. Вісник Львівського університету. - Серія: педагогічна [Bulletin of Lviv University. - Series: Pedagogy], No 22, pp. 227-231 (in Ukranian).

11. Синенко, В. (2012). Каскадная (циклическая) система повьшения квалификации работников образования [Cascade (Cyclic) System of Teaching Staff Advanced Training]. Вестник образования [Bulletin of Education], No 20, pp. 11-14 (in Russian).

12. Синенко, В. (2010). Система повышения квалификации работников образования - от кризиса в сознании до реальных перспектив [The System of Teaching Staff Advanced Training - from Crisis in Perception to Real Perspectives]. Сибирский учитель [Syberian Teacher], No 2, pp. 5-12 (in Russian). 